\title{
Effects of Herbaspirillum Sp. P5-19 Assisted With Alien Soil Improvement on the Phytoremediation of Copper Tailings by Vetiveria Zizanioides
}

\author{
Qing Fang \\ Anhui University \\ Tao Huang \\ Anhui University \\ Ning Wang \\ Anhui University \\ Ziwei Ding \\ Anhui University \\ Qingye Sun ( $\square$ sunqingye@ahu.edu.cn ) \\ Anhui University
}

\section{Research Article}

Keywords: microorganism, alien soil improvement, vetiver grass, remediation efficiency, heavy metals

Posted Date: March 9th, 2021

DOI: https://doi.org/10.21203/rs.3.rs-218378/v1

License: (1) This work is licensed under a Creative Commons Attribution 4.0 International License. Read Full License

Version of Record: A version of this preprint was published at Environmental Science and Pollution Research on July 27th, 2021. See the published version at https://doi.org/10.1007/s11356-021-15091-y. 


\section{Abstract}

This study investigated examined the potential of Herbaspirillum sp. p5-19 (p5-19) assisted with alien soil improvement on improving stress tolerance and enhancing the accumulation of $\mathrm{Mn}, \mathrm{Cu}, \mathrm{Zn}$ and $\mathrm{Cd}$ by vetiver grass (Vetiveria zizanioides). Phytoremediation potential was evaluated by plant biomass and the ability of plant to absorb and transfer heavy metals. Results showed that the biomass was increased by $19.64 \%-173.81 \%$ in p5-19 inoculation treatments with and without alien soil improvement compared with control. Meanwhile, photosynthetic pigment contents were enhanced in co-inoculation treatment (p5-19 with alien soil improvement). In addition, the malondialdehyde (MDA) content was decreased, and the activities of antioxidant enzymes such as ascorbate peroxidase (APX), superoxide dismutase (SOD), peroxidase (POD) and catalase (CAT) were increased in p5-19 treatment, thereby alleviating the oxidative stress. Moreover, co-inoculation significantly $(p<0.05)$ increased the concentrations of $\mathrm{Mn}, \mathrm{Cu}, \mathrm{Zn}$ and $\mathrm{Cd}$ in the roots and shoots of vetiver grass. In particular, the highest concentration of $\mathrm{Mn}, \mathrm{Zn}$ and $\mathrm{Cd}$ in the shoots (roots) were obtained in $\mathrm{C} 10$ under p5-19 inoculation (C10B), which were 4.44- (2.71-), 4.73- (3.87-) and 5.93- (4.35-) fold as that of the controls, respectively. These results provided basis for the change of phytoremediation ability of vetiver grass after inoculation. We concluded that p5-19 assisted with alien soil improvement was a potential strategy for enhancing phytoremediation ability in tailings.

\section{Introduction}

The development of the mining industry has led to increasingly serious heavy metal pollution (Han et al., 2008; Han et al., 2016). Heavy metals in tailings, such as manganese $(\mathrm{Mn})$, iron ( $\mathrm{Fe})$, copper $(\mathrm{Cu})$, zinc $(\mathrm{Zn})$, cadmium $(\mathrm{Cd})$ and lead $(\mathrm{Pb})$, pose great harm to ecosystems and agricultural systems and lead to certain risks to human health (Lu and Liu, 2018; Kang et al., 2019). Therefore, alternative solutions must be developed to solve this serious problem.

Phytoextraction is considered to be an environmentally friendly method for the extraction of heavy metals (Li et al., 2012; Sun et al., 2019). However, plants that are grown in tailings are at risk of heavy metal toxicity stress and irreversible damage, which lead to low biomass, thereby reducing remediation efficiency (Weyens et al., 2009; Chanda et al., 2017). Thence, efficient technologies must be introduced to improve the efficiency of phytoremediation.

Several studies have found that alien soil improvement can promote plant growth and increase heavy metal uptake in tailings (Maiti and Rana, 2017; Sun et al., 2017). Nejad et al. (2017) reported that red mud combined with revegetation could effectively stabilise arsenic (As) and prevent the dispersion of As through runoff and percolation around the mining site. Similarly, topsoil construction is an effective technique for mitigating heavy metal migration in tailing ponds (Zhang et al., 2016). In addition, some organic and inorganic materials in soil are good amendments, which can increase soil fertility, improve soil structure and enhance soil moisture content (Long et al., 2015; Azeez, 2019). As a low-cost and environmentally friendly material, soil is often used in tailing reclamation, providing nutrients to microorganisms and plants and improving phytoextraction efficiency; the concentrations of heavy metals in the tissues of plants grown on the reclaimed mine soil are higher than that of the unreclaimed control (Maiti and Rana, 2017). However, the enhancement of the phytoremediation ability in tailings by alien soil improvement is limited. Some microorganisms can reduce soil pH that promotes nutrient absorption by plants, enhance heavy metal bioavailability and improve plant growth (Deng et al., 2014; Ma et al., 2016a). Therefore, introducing suitable microorganisms to assist phytoremediation is necessary.

Moreover, in view of the existence of a symbiotic relationship between rhizosphere microbes and plants, phytoextraction assisted by plant growth-promoting bacteria (PGPB) may be a potential technology to improve the extraction efficiency in heavy metal-contaminated soil (Rojjanateeranaj et al., 2017). Various bacteria have been successfully involved in promoting plant growth and indirectly increasing the accumulation of heavy metals when plants are grown in tailings (Prapagdee et al., 2013; Srivastava et al., 2013). Herbaspirillum sp. can stimulate the secretion of plant hormones and increase host plant's production, and Herbaspirillum sp. GW103 can significantly improve $\mathrm{Pb}$ and $\mathrm{Zn}$ phytoextraction potential and the biomass of Zea mays through increasing protein content and decreasing metal phytotoxicity (Praburaman et al., 2017). Furthermore, inoculation with Herbaspirillum sp. SmR1 can promote the growth of crops such as Oryza sativa, Sorghum bicolor, Saccharum officinarum, and Triticum aestivum (Pedrosa et al., 2011). Consequently, the effect of combining microbes and alien soil improvement on phytoextraction must be analysed.

Vetiver grass (Vetiveria zizanioides) has been widely applied in the field of tailings ecological restoration because of its remarkable properties, including the tolerance of various heavy metals, strong root system, high biomass and rapid growth rate (Marques et al., 2009; Dudai et al., 2018; Chen et al., 2015). Therefore, vetiver grass has been selected as a phytoremediation species for the current experiment. 
We hypothesise that PGPB p5-19-inoculated vetiver grass assisted with alien soil improvement will provide effective guidance and insights into the phytoremediation of tailings. The specific objectives of this study are as follows: (1) to explore the effect of p5-19 assisted with alien soil improvement on the biomass and photosynthetic pigment contents, (2) to analyze the mechanism of p5-19 and alien soil improvement in increasing heavy metal tolerance of vetiver grass and (3) to evaluate the capacity of p5-19 combined with alien soil improvement on enhancing the phytoextraction of $\mathrm{Mn}, \mathrm{Cu}, \mathrm{Zn}$ and $\mathrm{Cd}$ in tailings.

\section{Materials And Methods}

\subsection{Tailings and soil preparation and analysis}

The samples used in this study were collected from 0-20 cm tailings on the surface of the Tongguanshan tailing pond in Tongling, Anhui, China (N3056 $\left.56^{\prime} 11^{\prime \prime} \mathrm{E} 117^{\circ} 51^{\prime} 35^{\prime \prime}\right)$. Soil for alien soil improvement was collected from $0-20 \mathrm{~cm}$ on the surface of the garden soil of Anhui University, Hefei, Anhui, China (N31 ${ }^{\circ} 46^{\prime} 22^{\prime \prime} \mathrm{E} 117^{\circ} 10^{\prime} 54^{\prime \prime}$ ). The soil was silty clay loam, and it consisted of $21.5 \%$ sand, $37.2 \%$ silt and $41.3 \%$ clay. Then, tailings and soil were air dried and sieved through a $2 \mathrm{~mm}$ sieve separately before filling in the pot (Zhong et al., 2020). Substrate pH and electric conductivity were measured in water (1 g:2.5 ml, substrate:water) (Zhang et al., 2018) using a pH meter (PHS3C, REX, Shanghai, China) and conductivity meter (DDB-303A, REX, Shanghai, China), respectively. The total and available nitrogen, phosphorus and potassium concentrations of the substrate were analysed according to the method of Lu (2000). Basic physical and chemical properties and heavy metal concentration of the substrate were listed in Table 1. The concentrations of $\mathrm{Cu}, \mathrm{Zn}$ and $\mathrm{Cd}$ in tailings were higher than the soil quality standard (SQS) of China (GB 15618 - 2018) (State Environmental Protection Administration of China, 2018), that is, for soils with $\mathrm{pH} 6.5-7.5$, the screening value of $\mathrm{Cu}, \mathrm{Zn}$ and $\mathrm{Cd}$ concentrations was 100,250 and $0.3 \mathrm{mg} \mathrm{kg}^{-1}$, respectively.

Table 1

Basic physical and chemical properties and heavy metals concentrations of substrate

\begin{tabular}{|c|c|c|c|c|c|c|c|c|c|}
\hline \multirow[t]{2}{*}{ Substrate } & \multirow{2}{*}{$\begin{array}{l}\mathrm{pH} \\
\text { value }\end{array}$} & \multirow{2}{*}{$\begin{array}{l}\text { Electric } \\
\text { conductivity }(\mu \mathrm{S} \\
\left.\mathrm{cm}^{-1}\right)\end{array}$} & \multirow{2}{*}{$\begin{array}{l}\text { Total } \\
\text { nitrogen } \\
\text { concentration } \\
\left(\mathrm{mg} \mathrm{kg}^{-1}\right)\end{array}$} & \multirow{2}{*}{$\begin{array}{l}\begin{array}{l}\text { Total } \\
\text { phosphorus } \\
\text { concentration }\end{array} \\
\left(\mathrm{mg} \mathrm{kg}^{-1}\right)\end{array}$} & \multirow{2}{*}{$\begin{array}{l}\begin{array}{l}\text { Total } \\
\text { potassium } \\
\text { concentration }\end{array} \\
\left(\mathrm{mg} \mathrm{kg}^{-1}\right)\end{array}$} & \multicolumn{4}{|c|}{ Heavy metals concentrations $\left(\mathrm{mg} \mathrm{kg}^{-1}\right)$} \\
\hline & & & & & & $\mathrm{Mn}$ & $\mathrm{Cu}$ & $\mathrm{Zn}$ & Cd \\
\hline Tailings & $\begin{array}{l}7.18 \\
\pm \\
0.01 \mathrm{~b}\end{array}$ & $711.66 \pm 3.24 b$ & $\begin{array}{l}262.01 \pm \\
4.72 \mathrm{c}\end{array}$ & $\begin{array}{l}170.15 \pm \\
3.15 b\end{array}$ & $\begin{array}{l}925.76 \pm \\
5.82 \mathrm{~d}\end{array}$ & $\begin{array}{l}2462.57 \\
\pm 96.25 \mathrm{a}\end{array}$ & $\begin{array}{l}447.08 \\
\pm \\
27.17 \mathrm{a}\end{array}$ & $\begin{array}{l}670.12 \\
\pm \\
32.16 \mathrm{a}\end{array}$ & $\begin{array}{l}2.47 \\
\pm \\
0.23 a\end{array}$ \\
\hline Soil & $\begin{array}{l}7.71 \\
\pm \\
0.02 a\end{array}$ & $\begin{array}{l}1822.71 \pm \\
8.78 a\end{array}$ & $\begin{array}{l}765.12 \pm \\
6.28 a\end{array}$ & $\begin{array}{l}1331.47 \pm \\
9.97 a\end{array}$ & $\begin{array}{l}1773.95 \pm \\
11.13 a\end{array}$ & $\begin{array}{l}314.24 \pm \\
12.12 \mathrm{c}\end{array}$ & $\begin{array}{l}21.49 \\
\pm 1.12 \mathrm{c}\end{array}$ & $\begin{array}{l}483.38 \\
\pm \\
21.31 \mathrm{c}\end{array}$ & $\begin{array}{l}0.24 \\
\pm \\
0.02 \mathrm{~b}\end{array}$ \\
\hline M10 & $\begin{array}{l}7.14 \\
\pm \\
0.01 \mathrm{~b}\end{array}$ & $724.10 \pm 2.46 b$ & $\begin{array}{l}272.88 \pm \\
3.80 \mathrm{bc}\end{array}$ & $\begin{array}{l}176.29 \pm \\
4.77 b\end{array}$ & $\begin{array}{l}952.94 \pm \\
17.57 c\end{array}$ & $\begin{array}{l}2378.48 \\
\pm \\
105.31 \mathrm{ab}\end{array}$ & $\begin{array}{l}447.08 \\
\pm \\
20.08 \mathrm{a}\end{array}$ & $\begin{array}{l}625.11 \\
\pm \\
33.53 \mathrm{~b}\end{array}$ & $\begin{array}{l}2.27 \\
\pm \\
0.30 \mathrm{a}\end{array}$ \\
\hline M20 & $\begin{array}{l}7.14 \\
\pm \\
0.01 \mathrm{~b}\end{array}$ & $729.51 \pm 2.03 b$ & $\begin{array}{l}284.46 \pm \\
5.87 \mathrm{~b}\end{array}$ & $\begin{array}{l}185.91 \pm \\
3.36 b\end{array}$ & $\begin{array}{l}980.54 \pm \\
6.37 b\end{array}$ & $\begin{array}{l}2299.82 \\
\pm 72.45 b\end{array}$ & $\begin{array}{l}407.27 \\
\pm \\
22.32 \mathrm{~b}\end{array}$ & $\begin{array}{l}612.14 \\
\pm \\
107.65 \mathrm{~b}\end{array}$ & $\begin{array}{l}2.03 \\
\pm \\
0.18 \mathrm{a}\end{array}$ \\
\hline
\end{tabular}

Notes: M10: $10 \%$ soil and 90\% tailings, M20: $20 \%$ soil and $80 \%$ tailings. Lowercase letters indicates significant differences among treatments, $p \otimes 0.05$ (Total samples $N=16$; Replication $n=4$ ).

\subsection{Traits of bacteria}

The strain of PGPB was Herbaspirillum sp. p5-19 (p5-19), which was isolated from rhizosphere tailings of Imperata cylindrica collected from Tongguanshan tailings pond in Tongling, Anhui, China. The major plant growth promoting traits of p5-19 were analysed, including phosphate solubilizing activity (Pikovskaya R.I., 1948), IAA-producing capability (Bric et al, 1991), siderophore production (Schwyn and Neilands, 1987) and nitrogen fixation test (Hardy et al., 1968).

\subsection{Inoculation of bacterium}

Cell suspensions of p5-19 was grown in Luria-Bertani (LB) medium at $37^{\circ} \mathrm{C}$ and $180 \mathrm{rpm}$ (Prapagdee et al., 2012). After centrifuging at

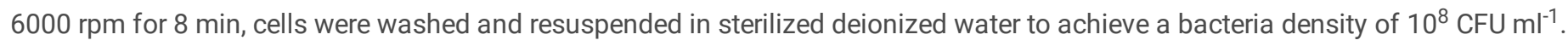

\subsection{Experimental design and pot experiment}


Two sets of pot experiments of vetiver grass have been established, including non-inoculation and p5-19 inoculation experiments. Each set was divided into five treatments: i) tailings (the un-improved control), ii) $10 \%$ soil and $90 \%$ tailings (w/w, intensive mixing), iii) $20 \%$ soil and $80 \%$ tailings, iv) covering $5 \mathrm{~cm}$ of soil and v) covering $10 \mathrm{~cm}$ of soil. Plastic pots (high $=27 \mathrm{~cm}$, diameter $=27 \mathrm{~cm}$ ) were used for the current experiment, and the holes in the bottom of the pot were covered with a non-woven cloth. The specific experimental design was shown in Table 2. Each group contained four replicates. After the soil and tailings were placed into the pot, they were watered until all the substrates were wetted and stored for a week to achieve substrate equilibrium (Liu et al., 2020). Then, three vetiver grass seedlings with the same growth status were planted in each pot, which were previously planted in garden soil without metal contamination for 2 weeks. Moreover, $40 \mathrm{ml}$ of the bacterial suspension was added to the pots that need to be inoculated, and the non-inoculated pots were replaced with $40 \mathrm{ml}$ of sterilised deionised water (Li et al., 2016). All pots were placed at a greenhouse with no shelter amongst plants, and the moisture content of each pot was $60 \%$. After 2 months, the roots of the plants extended into the bottom of the pot. All the vetiver grasses were harvested, and the plants were rinsed several times with deionised water. In addition, the substrate samples that adhered to the roots were collected for further analysis. Available nutrient elements (N, P and K) and heavy metal concentrations of substrate were shown in Table S1.

Table 2

Experiment design

\begin{tabular}{|c|c|c|c|c|c|c|c|c|c|c|}
\hline Treatment & $\mathrm{CK}^{\mathrm{a}}$ & $\mathrm{B}^{\mathrm{b}}$ & M10 & $M 10 B^{d}$ & $\mathrm{M} 2 \mathrm{O}^{\mathrm{e}}$ & $M 20 B^{f}$ & $\mathrm{C} 5^{\mathrm{g}}$ & C5B ${ }^{h}$ & $\mathrm{C} 10^{\mathrm{i}}$ & $\mathrm{C} 10 \mathrm{~B}^{\mathrm{j}}$ \\
\hline Soil mass (kg) & 0 & 0 & 1.2 & 1.2 & 2.4 & 2.4 & 2.0 & 2.0 & 5.0 & 5.0 \\
\hline Tailings mass $(\mathrm{kg})$ & 12.0 & 12.0 & 10.8 & 10.8 & 9.6 & 9.6 & 10.0 & 10.0 & 7.0 & 7.0 \\
\hline Total mass (kg) & 12.0 & 12.0 & 12.0 & 12.0 & 12.0 & 12.0 & 12.0 & 12.0 & 12.0 & 12.0 \\
\hline bacterial suspension (ml) & 0 & 40.0 & 0 & 40.0 & 0 & 40.0 & 0 & 40.0 & 0 & 40.0 \\
\hline deionized water $(\mathrm{ml})$ & 40.0 & 0 & 40.0 & 0 & 40.0 & 0 & 40.0 & 0 & 40.0 & 0 \\
\hline
\end{tabular}

Notes: $^{a}$ tailings( the un-improved control ), b tailings with bacterial suspension(Herbaspirillum sp. p5-19), ${ }^{c} 10 \%$ soil and $90 \%$ tailings(w/w), d $10 \%$ soil and $90 \%$ tailings (with bacterial suspension), ${ }^{e} 20 \%$ soil and $80 \%$ tailings, ${ }^{f} 20 \%$ soil and $80 \%$ tailings (with bacterial suspension), ${ }^{\mathrm{g}}$ covering $5 \mathrm{~cm}$ of soil, ${ }^{\mathrm{h}}$ covering $5 \mathrm{~cm}$ of soil (with bacterial suspension), ${ }^{\mathrm{i}}$ covering $10 \mathrm{~cm}$ of soil, ${ }^{\mathrm{j}}$ covering $10 \mathrm{~cm}$ of soil (with bacterial suspension).

\subsection{Plant physiological characteristic analysis}

\subsubsection{Plant antioxidant enzymes}

The activity of ascorbate peroxidase (APX) was measured as the decrease in absorbance at $290 \mathrm{~nm}$ (Nakano and Asada, 1981). The level of lipid peroxidation in vetiver grass was evaluated by malondialdehyde (MDA) content, which was the production of lipid peroxidation after reacting with thiobarbituric acid (TBA) (Heath and Packer, 1968). Superoxide dismutase (SOD) activity was defined as the photoreduction of nitro-bluetetrazolium (NBT) at $560 \mathrm{~nm}$ about $50 \%$ and detected by measuring its ability to inhibit the photo-reduction of NBT (Beauchamp and Fridovich, 1971). Peroxidase (POD) activity was assayed by monitoring the increase of absorbance at $460 \mathrm{~nm}$ because of the oxidation of guaiacol following the method of Omran (1980). Catalase (CAT) activity was measured according to Aebi (1984).

\subsubsection{Plant biomass and photosynthetic pigments contents}

The fresh plants were cured in an oven at $105^{\circ} \mathrm{C}$ for $30 \mathrm{~min}$ and then dried at $75^{\circ} \mathrm{C}$ to a constant weight, and the dried plants were weighed. The photosynthetic pigment contents of vetiver grass were measured by the modified method of Arnon (1949), and fresh leaves were cut into small pieces, avoiding major veins, removing $0.1 \mathrm{~g}$ of leaves and soaking them in $8 \mathrm{ml}$ of $80 \%$ aqueous acetone solution. The photosynthetic pigment contents were determined using an ultraviolet spectrophotometer (TU-1901, Purkinje, Beijing, China) at wavelengths of 663,645 and $470 \mathrm{~nm}$ after the extraction was completed.

\subsection{Heavy metal analysis}

Total concentrations of $\mathrm{Mn}, \mathrm{Cu}, \mathrm{Zn}$ and $\mathrm{Cd}$ in the substrate samples were determined by inductively coupled plasma mass spectrometry (ICP-MS, Thermo, Waltham, MA, USA) after digesting with $5 \mathrm{ml}$ of concentrated nitric acid $\left(\mathrm{HNO}_{3}\right), 5 \mathrm{ml}$ of concentrated hydrofluoric acid (HF) and $2 \mathrm{ml}$ of concentrated perchloric acid $\left(\mathrm{HCLO}_{4}\right)$ (Li et al., 2016; Faust and Christians, 2000). Standard reference material GSS-15 was used for quality control of the analytical procedure. Available heavy metals were extracted by DTPA-CaCl$-\mathrm{TEA}$ at pH 7.3 (Baker and Amacher, 1982) and quantified by ICP-MS. 
For the estimation of heavy metal element concentration of vetiver grass, the plant samples $(0.1 \mathrm{~g})$ were digested with $5 \mathrm{ml}$ of concentrated $\mathrm{HNO}_{3}$ and $1 \mathrm{ml}$ of hydrogen peroxide $\left(\mathrm{H}_{2} \mathrm{O}_{2}\right)(5: 2, \mathrm{v} / \mathrm{v})$. Then, the same analysis method was used. Standard reference samples (GBW10020 and GBW10048) were used for quality control of the analytical procedure.

\subsection{Data and statistical analyses}

\subsubsection{Calculation of mobility and extraction efficiency}

The bioconcentration factor (BCF) represents the ability of plants to accumulate heavy metals from tailings, and the translocation factor (TF) indicates the effectiveness of plants to transport heavy metals from the roots to the shoots (Mijani et al., 2016; Lam et al., 2017, 2018). They can be calculated according to the following formula (Zeng et al., 2019; Xiao et al., 2019).

$$
\begin{array}{r}
T F=\frac{C_{\text {shoot }}}{C_{\text {root }}} \\
B C F=\frac{\mathrm{C}_{\text {shoot or root }}}{\mathrm{C}_{\text {substrate }}}
\end{array}
$$

Where the $\mathrm{C}_{\text {shoot}}, \mathrm{C}_{\text {root }}$ and $\mathrm{C}_{\text {substrate }}$ are represent the concentrations of heavy metals $\left(\mathrm{mg} \mathrm{kg}^{-1}\right)$ in harvest parts (shoot and root) and substrate, respectively.

\subsubsection{Statistical analyses}

The Kolmogorov-Smirnov test was applied to ensure the normality of the data. Mean and standard deviation values were used to represent all analytical results. Twenty-five separate one-way ANOVA were applied to analyse the physiological indicators (dry weight, chlorophyll a, chlorophyll b, carotenoid,MDA, APX, POD, CAT and SOD), heavy metal concentration ( $\mathrm{Mn}, \mathrm{Cu}, \mathrm{Zn}$ and $\mathrm{Cd}$ in roots and shoots) and $\mathrm{BCF}(\mathrm{Mn}, \mathrm{Cu}, \mathrm{Zn}$ and $\mathrm{Cd}$ in roots and shoots) of plants. For the analysis of TF value, two-way ANOVA was applied. The factors were treatments (CK, B, M10, M10B, M20, M20B, C5, C5B, C10 and C10B) and heavy metals (Mn, Cu, Zn and Cd). ANOVA followed by Tukey's test at a significance level of 0.05 was conducted to obtain the significant difference amongst different treatments. The abovementioned work was achieved through SPSS 21.0. Figures were drawn using Origin 9.0 software program.

\section{Result And Discussion}

\subsection{Plant growth-promoting traits of p5-19}

The plant growth-promoting traits of p5-19 were shown in Table 3. The IAA production of p5-19 was relatively higher than that of other bacterial isolates such as Herbaspirillum sp. GW103, which could produce $9.05 \mathrm{\mu g} \mathrm{ml}^{-1}$ of IAA (Praburaman et al., 2017). The secretion of siderophores could indirectly strengthen plant growth (Tortora et al., 2011). In addition, the isolated strains could fix nitrogen and solubilise phosphate.

Table 3

\begin{tabular}{|c|c|c|c|c|}
\hline Strain & $\begin{array}{l}\text { IAA synthesis } \\
/ \mu \mathrm{g} \cdot \mathrm{ml}^{-1}\end{array}$ & siderophore production & $\begin{array}{l}\text { Phosphate solubilization } \\
/ \mathrm{mg} \cdot 100 \mathrm{ml}^{-1}\end{array}$ & Nitrogen fixation \\
\hline P5-19 & $55.36 \pm 1.78$ & + & $4.51 \pm 0.32$ & + \\
\hline
\end{tabular}

Traits of p5-19

\subsection{Biomass and photosynthetic pigment contents of vetiver grass}

Biomass and photosynthetic pigment contents are important indicators to estimate plant growth (Tang et al., 2020; Perez et al., 2020). In this study, plant biomass was evaluated by plant dry weight (DW) (Liu et al., 2020). The DW of vetiver grasses increased in all treatments compared with CK (Fig. 1). Alien soil improvement enhanced DW by 19.64-126.25\%, and C10 treatment had higher DW than other alien soil improvement treatments. In addition, treatments with p5-19 had a better effect on increasing DW of vetiver grasses than other treatments without p5-19. Meanwhile, the chlorophyll $a$ and $b$ and carotenoid content of vetiver grasses were increased in treatments 
compared with CK. The photosynthetic pigment contents of vetiver grasses at $\mathrm{C} 10$ treatment significantly increased compared with $\mathrm{CK}$ (by $208.8 \%, 220.7 \%$ and $85.1 \%$ ). Furthermore, treatment inoculated with p5-19 could enhance photosynthetic pigment contents.

Soil was used to improve tailing properties because it contained a higher nutrient content than tailings, and it can be easily obtained (Jordán et al., 2016). As shown in Table 2, C10 treatment corresponds to the highest soil mass and provides an uncontaminated surface for plant growth, which may indicate that the biomass and photosynthetic pigment contents of vetiver grass have reached the maximum in $\mathrm{C} 10$. The results also indicated that p5-19 had the potential to promote plant growth under heavy metal stress. P5-19 could secrete IAA, produce siderophores, fix nitrogen and solubilise phosphate (Table 3), which could increase available N, P and K concentrations of the substrate (Table S1), thereby generating important effects on plant growth. The results confirmed that p5-19 assisted with alien soil improvement was more efficient on promoting plant growth in tailings than single ones.

\subsection{Lipid peroxidation and reactive oxygen species (ROS) scavenging system}

MDA is the primary product of lipid peroxidation under heavy metal stress, which can indicate the extent of damage to the cell membrane of plant cells. APX, POD, CAT and SOD play a major role in decreasing the oxidative damage of heavy metals by scavenging ROS. As shown in Fig. 2a, MDA content decreased in all alien soil improvement treatments, and a significant reduction was found in co-inoculation (p5-19 and alien soil improvement) treatments. The minimum level of MDA was obtained in C10B. The MDA levels in treatments with p519 were lower (7.47-18.36\%) than those in non-inoculation treatments. The activities of APX, POD, CAT and SOD decreased after alien soil improvement (without p5-19 inoculation, Figs. 2b-e). APX activities had an evident decline by $20.10-75.96 \%$ in all treatments without p5-19 compared with CK, but the activity of APX enhanced in the presence of p5-19 and increased by $12.76 \%, 25.04 \%, 43.91 \%$, $38.96 \%$ and $55.74 \%$ in $\mathrm{CK}, \mathrm{M} 10, \mathrm{M} 20, \mathrm{C} 5$ and $\mathrm{C} 10$, respectively. An evident difference was observed on POD activities under alien soil improvement compared with CK, whereas the POD activity could maintain a high level with the application of p5-19 amongst all treatments. In addition, the activities of APX and POD improved significantly with the application of p5-19 in the alien soil improvement treatments, which indicated that alien soil improvement could assist p5-19 to enhance APX and POD activities. A significant change in CAT activity was detected in most treatments compared with CK (without p5-19 inoculation), and the effect of p5-19 on improving CAT activity was insignificant in all treatments. The activity of SOD decreased distinctly with the covering soil treatments and reached a minimum value of $1189.10 \mathrm{U} \mathrm{g}^{-1} \mathrm{~h}^{-1}$ in $\mathrm{C} 10$. With the application of $\mathrm{p5}-19$, the SOD activity increased to a higher level compared with the uninoculated control.

In the current study, the levels of MDA and all analysed antioxidant enzymes were reduced to a certain extent under alien soil improvement strategies. These results indicated that different alien soil improvement treatments effectively alleviated the stress of heavy metals, and covering soil treatments were more effective than mixing soil treatments on alleviating stress probably because the organic and inorganic matter (silica, alumina and magnesium oxide) in soil adsorbed, complexed and exchanged with heavy metals in tailings and ultimately reduced metal toxicity. Organic amendments stabilised heavy metal by attaching heavy metal content with organic matter (Gul et al., 2020). Some organics reduce the availability of heavy metals through adsorption reactions (Pardo et al., 2014). In addition, inorganic substances can form insoluble compounds with heavy metals, thereby reducing the bioavailability of heavy metals (Acosta et al., 2018). Moreover, most antioxidants levels decrease in $\mathrm{C} 10$ treatment compared with other treatments probably because the amount of soil added and the method of adding soil can affect the improvement effect. Four types of alien soil improvement strategies could reduce the phytotoxicity of heavy metals and improve substrate environment, of which C10 was the most effective improvement method.

On the contrary, with the application of p5-19, antioxidant enzyme activities incerased to a higher level under heavy metal stress possibly bacause Herbaspirillum could improve the micro-environment of vetiver grass by secreting IAA and siderophores, thereby enhancing plant resistance against metal stress by regulating antioxidant enzyme activities (Daniel et al., 2013). In addition, some secondary metabolites excreted by p5-19 could activate heavy metals in tailings (Praburaman et al., 2017; Rojjanateeranaj et al., 2017). Furthermore, inoculation increased available heavy metal concentrations (Table S1), which induced the plant antioxidant defence system. The levels of APX and POD increased significantly with the supply of p5-19 after alien soil improvement treatments. Alien soil improvement could improve the micro-environment of the tailing plant system and provide nutrient for microorganisms, which indicated that co-inoculation could effectively relief stress of heavy metals and enhance the antioxidant ability of vetiver grass.

\subsection{Heavy metal accumulation and translocation}

The concentrations of $\mathrm{Mn}, \mathrm{Cu}, \mathrm{Zn}$ and $\mathrm{Cd}$ that accumulated in the shoot and root of vetiver grass under different alien soil improvement treatments with and without p5-19 were presented in Fig. 3. In the absence of p5-19, Mn concentration of vetiver grass in the shoots and roots increased significantly in M20, C5 and C10 treatments compared with CK (Figs. 3a-b). Different from Mn, alien soil improvement

Page 6/13 
had a little effect on Cu concentration in vetiver grass, and Cu concentration only significantly enhanced in C5 treatment (Figs. 3c-d). Alien soil improvements significantly promoted the absorption of $\mathrm{Zn}$ and $\mathrm{Cd}$ by vetiver grass roots (except for M10), but $\mathrm{Zn}$ and $\mathrm{Cd}$ concentrations in plant shoots could only be enhanced in $\mathrm{C} 10$ (Figs. 3e-h). These results indicate that the nitrogen and phosphorus compounds in soil provide a suitable growth environment for plants and microorganisms (Xu et al., 2014; Krzysztof and Fijalkowski, 2020), thereby improving the uptake of heavy metals by promoting plant growth. Our study also found that co-inoculation could increase the heavy metal concentrations in vetiver grasses compared with the single alien soil improvement treatments. The highest concentrations of $\mathrm{Mn}$ (467.69 $\mathrm{mg} \mathrm{kg}^{-1}$ in shoot and $519.60 \mathrm{mg} \mathrm{kg}^{-1}$ in root), Zn (65.22 mg kg${ }^{-1}$ in shoot and $125.13 \mathrm{mg} \mathrm{kg}^{-1}$ in root) and $\mathrm{Cd}\left(0.65 \mathrm{mg} \mathrm{kg}^{-1}\right.$ in shoot and $1.13 \mathrm{mg} \mathrm{kg}^{-1}$ in root) were observed in C10B. PGPB enhanced metal accumulation by increasing the bioavailability of different metals. Furthermore, PGPB decreased substrate $\mathrm{pH}$ that assisted nutrient and metal absorption by plants (Kamran et al., 2016). This result was consistent with that obtained by Ma et al. (2016b), which indicated that inoculation of PGPB Pseudomonas libanensis TR1 and Pseudomonas reactans Ph3R3 increased the $\mathrm{Cu}$ and $\mathrm{Zn}$ accumulation in Brassica oxyrrhina. By contrast, Mousavi et al. (2018) found that $\mathrm{Zn}$ and $\mathrm{Pb}$ accumulation in sunflower increased with the addition of Bacillus safensis $\mathrm{FO}-036 \mathrm{~b}$ ( $\mathrm{T}$ ) and Pseudomonas fluorescens p.f. 169 as compared with the control plants. In addition, compared with single treatment, coinoculation could promote the uptake of heavy metals by vetiver grass possibly because alien soil improvement increased the nutrient content of tailings and activated indigenous or inoculated microbial activities (Mahbub et al., 2017). However, the specific mechanism needs further study.

As shown in Fig. 3, the trends of $\mathrm{BCF}$ of $\mathrm{Mn}, \mathrm{Cu}, \mathrm{Zn}$ and $\mathrm{Cd}$ in vetiver grasses were consistent with $\mathrm{Mn}, \mathrm{Cu}, \mathrm{Zn}$ and $\mathrm{Cd}$ concentrations in plants with different treatments. The co-inoculation treatment effectively increased the BCF of metals in different parts of vetiver grass. The BCF of the roots was higher than that of the shoots, and the BCF of $\mathrm{Mn}, \mathrm{Cu}, \mathrm{Zn}$ and $\mathrm{Cd}$ in the roots at $\mathrm{C} 10 \mathrm{~B}$ treatment reached a maximum of $0.503,0.409,0.233$ and 1.228 , respectively. The BCF of $\mathrm{Cd}$ in the shoots and roots in all treatments was higher than that of other heavy metals, and the BCF of $\mathrm{Cd}$ in the roots in $\mathrm{C10B}$ was more than 1.00 . This result is caused by the strategies that different heavy metals used in entering the plant. Zhang et al. (2014) also obtained similar results and documented that Cd entered the vetiver grass roots through the Fe and $\mathrm{Mn}$ carrier.

Alien soil improvement had a little effect on heavy metal translocation, and the $\mathrm{Cu}$ and $\mathrm{Cd}$ translocation in plants showed no significant difference at p5-19 treatment. Nevertheless, the TF of Zn enhanced markedly under p5-19 inoculation (Table 4). These results are related to the tolerance of different tissues of plants to various metal ions (Grant et al., 1998). The TF value of Mn and $\mathrm{Zn}$ reached the maximum at C10B, which increased $55.80 \%$ and $28.67 \%$ than that of the control, respectively.

Table 4

Influence of p5-19 and alien soil improvement on heavy metal translocation by vetiver grass

\begin{tabular}{|c|c|c|c|c|}
\hline \multirow[t]{2}{*}{ Treatments } & \multicolumn{4}{|l|}{ TF } \\
\hline & Mn & $\mathrm{Cu}$ & Zn & $\mathrm{Cd}$ \\
\hline CK & $0.552 \pm 0.035 c$ & $0.078 \pm 0.005 \mathrm{ab}$ & $0.429 \pm 0.036 b c$ & $0.424 \pm 0.058 \mathrm{ab}$ \\
\hline B & $0.659 \pm 0.066 b c$ & $0.077 \pm 0.005 \mathrm{ab}$ & $0.512 \pm 0.045 a$ & $0.504 \pm 0.052 a b$ \\
\hline M10 & $0.548 \pm 0.151 c$ & $0.092 \pm 0.014 a$ & $0.391 \pm 0.057 b c$ & $0.421 \pm 0.129 a b$ \\
\hline M10B & $0.643 \pm 0.041 b c$ & $0.090 \pm 0.007 a$ & $0.523 \pm 0.038 a$ & $0.517 \pm 0.083 a b$ \\
\hline M20 & $0.551 \pm 0.080 c$ & $0.073 \pm 0.004 a b$ & $0.355 \pm 0.075 \mathrm{~cd}$ & $0.456 \pm 0.076 a b$ \\
\hline M20B & $0.663 \pm 0.012 b c$ & $0.075 \pm 0.002 \mathrm{ab}$ & $0.496 \pm 0.025 a b$ & $0.608 \pm 0.081 a$ \\
\hline C5 & $0.627 \pm 0.100 \mathrm{bc}$ & $0.079 \pm 0.013 \mathrm{ab}$ & $0.252 \pm 0.069 d$ & $0.384 \pm 0.053 b$ \\
\hline C5B & $0.773 \pm 0.028 a b$ & $0.075 \pm 0.006 a b$ & $0.314 \pm 0.009 \mathrm{~cd}$ & $0.438 \pm 0.077 a b$ \\
\hline C10 & $0.876 \pm 0.067 a$ & $0.064 \pm 0.003 b$ & $0.429 \pm 0.064 b c$ & $0.475 \pm 0.145 a b$ \\
\hline C10B & $0.860 \pm 0.007 a$ & $0.069 \pm 0.012 b$ & $0.522 \pm 0.023 a$ & $0.579 \pm 0.053 \mathrm{ab}$ \\
\hline
\end{tabular}

Lowercase letters indicates significant differences among treatments, $p \otimes 0.05$ (Total samples $N=40$; Replication $n=4$ ). Notes: $C K$ : Tailings (the un-improved control), B: Tailings with bacterial suspension (Herbaspirillum sp. p5-19), M10: 10\% soil and 90\% tailings, M10B: 10\% soil and 90\% tailings (with bacterial suspension), M20: $20 \%$ soil and $80 \%$ tailings, M20B: $20 \%$ soil and $80 \%$ tailings (with bacterial 
suspension), C5: Covering $5 \mathrm{~cm}$ of soil, C5B: Covering $5 \mathrm{~cm}$ of soil (with bacterial suspension), C10: Covering $10 \mathrm{~cm}$ of soil, C10B: Covering $10 \mathrm{~cm}$ of soil (with bacterial suspension).

\section{Conclusion}

P5-19 combined with alien soil improvement has the potential to boost the phytoextraction of heavy metals from tailings because of their enhanced plant growth and improved heavy metal availability. Moreover, exogenous application of p5-19 alleviates heavy metal-induced oxidative stress by stimulating the antioxidant defence system. The maximum BCF of heavy metals is obtained with the application of p5-19 combined with C10. In addition, plant biomass and antioxidant enzyme levels reach the highest efficiency compared with other treatments. Therefore, p5-19 with $\mathrm{C} 10$ by vetiver grass is a suitable strategy with excellent performance in the bioremediation of tailings particularly for Cd-contaminated soil, rendering great potential for practical application. Future studies will use p5-19 as a biofertiliser application in the reclamation of tailing ponds to determine the remediation efficiency under a practical environment.

\section{Declarations}

Ethics approval and consent to participate: Not applicable.

Consent to Publish: Not applicable.

\section{Authors Contributions:}

Qing Fang: Conceptualization, Investigation, Software, Formal analysis, Writing -

Original Draft.

Tao Huang: Software, Investigation, Methodology.

Ning Wang: Investigation, Formal analysis.

Ziwei Ding: Investigation.

Qingye Sun: Methodology, Funding acquisition, Project administration.

Competing Interests: The authors declare that they have no competing interests.

Availability of data and materials: All data generated or analyzed during this study are included in this published article.

\section{Acknowledgements}

This work was financially supported by Key Research and Development Projects in Anhui Province (201904a020027).

\section{References}

1. Acosta, J.A., Abbaspour, A., Martinez, G.R., Martinez-Martinez, S., Zornoza, R., Gabarron, M., Faz, A., 2018. Phytoremediation of mine tailings with Atriplex halimus and organic/inorganic amendments: A five-year field case study. Chemosphere 204,71-78.

2. Aebi, H., 1984. Catalase in vitro. Methods Enzymol 105, 121-126.

3. Arnon, D.I., 1949. Copper Enzymes in Isolated Chloropl Asts, Polyphenoxidase in Beta Vulgaris. Plant Physiol. 24, 1-15.

4. Azeez, J.O., 2019. Recycling organic waste in managed tropical forest ecosystems:effects of arboreal litter types on soil chemical properties in Abeokuta, southwestern Nigeria. For. Res. 5, 1903-1911.

5. Baker, D.E., Amacher, M.C., 1982. Nickel, copper, zinc and cadmium. In: Page, A.L., Millers, R.H., Keeney, D.R. (Eds.), Methods of Soil Analysis Part 2: Chimical and Microbiological Properties, 2nd Ed. Agronomy Monograph No. 9, American Society of Agronomy, Madison, pp. 323-334.

6. Beauchamp, C., Fridovich, I., 1971. Superoxide dismutase: Improved assays and an assay applicable to acrylamide gels. Anal. Biochem. 44, 276-287.

7. Bric, J.M., Bostock, R.M., Silverstone, S.E., 1991. Rapid in situ assay for indoleacetic Acid production by bacteria immobilized on a nitrocellulose membrane. Appl. Environ. Microbiol. 57, 535-538. 
8. Chanda, D., Sharma, G.D., Jha, D.K., Hijri, M., 2017. Tolerance of Microorganisms in Soil Contaminated with Trace Metals: An Overview. Recent advances in Applied Microbiology, pp. 165-193.

9. Chen, M., Xu, P., Zeng, G., Yang, C., Huang, D., Zhang, J., 2015. Bioremediation of soils contaminated with polycyclic aromatic hydrocarbons, petroleum, pesticides, chlorophenols and heavy metals by composting: applications, microbes and future research needs. Biotechnol. Adv. 33, 745-755.

10. Daniel, S., Yang, H., Liu, Y., Tatsiana, T., Uwe, L., 2013. Root ethylene signalling is involved in Miscanthus sinensis growth promotion by the bacterial endophyte Herbaspirillum frisingense J. Exp. Bot. 64(14), 4603-4615.

11. Deng, Z.J., Zhang, R.D., Shi, Y., Hu, L., Tan, H.M., Cao, L.X., 2014. Characterization of Cd-, Pb-, Zn-resistant endophytic Lasiodiplodia sp. MXSF31 from metal accumulating Portulaca oleracea and its potential in promoting the growth of rape in metal-contaminated soils. Environ. Sci. Pollut. Res. Int. 21, 2346-2357.

12. Dudai, N., Tsion, I., Shamir, S.Z., Nitzan, N., Chaimovitsh, D., Shachter, A., Haim, A., 2018. Agronomic and economic evaluation of Vetiver grass (Vetiveria zizanioides L.) as means for phytoremediation of diesel polluted soils in Israel. J. Environ. Manage. 211, 247255.

13. Faust, M.B., Christians, N.E., 2000. Copper Reduces Shoot Growth and Root Development of Creeping Bentgrass. Crop Sci. 40.

14. Grant, C.A., Buckley, W.T., Bailey, L.D., Selles, F., 1998. Cadmium accumulation in crops. J. Plant Sci. 78, 1-17.

15. Gul, I., Manzoor, M., Kallerhoff, J., Arshad, M., 2020. Enhanced phytoremediation of lead by soil applied organic and inorganic amendments: $\mathrm{Pb}$ phytoavailability, accumulation and metal recovery. Chemosphere 258, 127405.

16. Han, Y.L., Huang, S.Z., Gu, J.G., Qiu, S., Chen, J.M., 2008. Tolerance and accumulation of lead by species of Iris Ecotoxicology 17, 853859.

17. Han, Y., Wu, X., Gu, J., Zhao, J., Huang, S., Yuan, H., Fu, J., 2016. Effects of organic acids on the photosynthetic and antioxidant properties and accumulations of heavy metals of Melilotus officinalis grown in Cu tailing. Sci. Pollut. Res. 23, 17901-17909.

18. Hardy, R.W.F., Holsten, R.D., Burns, E.K.J.C., 1968. The acetylene-ethylene assay for nitrogen fixation: laboratory and field evaluation assay for nitrogen evaluation. Plant Physiol. 43, 1185-1207.

19. Heath, R.L., Packer, L., 1968. Photoperoxidation in isolated chloroplasts: I. Kinetics and stoichiometry of fatty acid peroxidation. Biochem. Biophys. 125, 189-198.

20. Jordán, M.M., García-Sánchez, E., Almendro-Candel, M.B., Pardo, F., Bech, J., 2016. Technosols designed for rehabilitation of mining activities using mine spoils and biosolids. Ion mobility and correlations using percolation columns. Catena 148, 74-80.

21. Kamran, M.A., Eqain, S.A.M.A.S., Bibi, S., Xu, R.K., Amna, Monis, M.F.H., Katsoyiannis, A., Bokhari, H., Chaudhary, H.J., 2016. Bioaccumulation of nickel by E. sativa and role of plant growth promoting rhizobacteria (PGPRs) under nickel stress. Ecotoxicol. Environ. Saf. 126, 256-263.

22. Kang, M.J., Kwon, Y.K., Yu, S., Lee, P.K., Park, H.S., Song, N., 2019. Assessment of Zn pollution sources and apportionment in agricultural soils impacted by a Zn smelter in South Korea. hazard. Mater. 364, 475-487.

23. Krzysztof, L., Fijalkowski, A.K.K., 2020. Phytotoxicity assay to assess sewage sludge phytoremediation rate using guaiacol peroxidase activity (GPX): A comparison of four growth substrates. Environ. Manage. 263, 110413.

24. Lam, E.J., Cánovas, M., Gálvez, M.E., Montofré, í.L., Keith, B.F., Faz, A., 2017. Evaluation of the phytoremediation potential of native plants growing on a copper mine tailing in northern Chile. Geochem. Explor. 182, 210-217.

25. Lam, E.J., Gálvez, M.E., Cánovas, M., Montofré, í.L., Keith, B.F., 2018. Assessment of the adaptive capacity of plant species in copper mine tailings in arid and semiarid environments. Soils Sediments 18(6), 2203-2216.

26. Li, H.Y., Wei, D.Q., Shen, M., Zhou, Z.P., 2012. Endophytes and their role in phytoremediation. Fungal Diversity 54, 11-18.

27. Li, X., Dong, S., Yao, Y., Shi, W., Wu, M., Xu, H., 2016. Inoculation of bacteria for the bioremediation of heavy metals contaminated soil by Agrocybe aegerita. RSC Adv. 6, 65816-65824.

28. Liu, H., Xie, Y., Li, J., Zeng, G., Li, H., Xu, F., Feng, S., Xu, H., 2020. Effect of Serratia K3 combined with organic materials on cadmium migration in soil-vetiveria zizanioides L. system and bacterial community in contaminated soil. Chemosphere $242,125164$.

29. Long, P., Sui, P., Gao, W.S., Wang, B.B., Huang, J.X., Yan, L.L., Yan, P., Zou, J.X., Chen, Y.Q., 2015. Aggregate stability and associated C and $\mathrm{N}$ in a silty loam soil as affected by organic material inputs. J. Integr. Agric. 14(4), 774-787.

30. Lu, R.K., 2000. Analytical Methods of Agricultural Chemistry in Soil Science. China Agricultural Scientech Press, Beijing, China.

31. Lu, Z., Liu, Z., 2018. Pollution characteristics and risk assessment of uranium and heavy metals of agricultural soil around the uranium tailing reservoir in Southern China. Radioanal. Nucl. Chem. 318, 923-933. 
32. Ma, Y., Rajkumar, M., Zhang, C., Freitas, H., 2016. Beneficial role of bacterial endophytes in heavy metal phytoremediation. J. Environ. Manage. 174, 14-25.

33. Ma, Y., Rajkumar, M., Zhang, C., Freitas, H., 2016. Inoculation of Brassica oxyrrhina with plant growth promoting bacteria for the improvement of heavy metal phytoremediation under drought conditions. J. Hazard. Mater. 320, 36-44.

34. Mahbub, K.R., Krishnan, K.M., Andrews, S., Venter, H., Naidu, R., Megharaj, M., 2017. Bio-augmentation and nutrient amendment decrease concentration of mercury in contaminated soil. Total Environ. 576, 303-309.

35. Maiti, S.K., Rana, V., 2017. Assessment of heavy metals contamination in reclaimed mine soil and their accumulation and distribution in Eucalyptus hybrid. Environ. Contam. Toxicol. 98(1), 97-104.

36. Marques, A.P., Rangel, A.O., Castro, P.M., 2009. Remediation of heavy metal contaminated soils: phytoremediation as a potentially promising clean-up technology. Rev. Environ. Sci. Technol. 39, 622-654.

37. Mijani, S., Hammami, H., Parsa, M., Mohassel, M.H.R., Rahim, S., 2016. Weeds Ability to Phytoremediate Cadmium-Contaminated Soil. J. Phytorem. 18(1), 48-53.

38. Mousavi, S.M., Motesharezadeh, B., Hosseini, H.M., Alikhani, H., Zolfaghari, A.A., 2018. Root-induced changes of Zn and Pb dynamics in the rhizosphere of sunflower with different plant growth promoting treatments in a heavily contaminated soil. Ecotoxicol. Environ. Saf. 147, 206-216.

39. Nakano, Y., Asada, K., 1981. Hydrogen Peroxide is Scavenged by Ascorbate-specific Peroxidase in Spinach Chloroplasts. Plant Cell Physiol. 22, 867-880.

40. Nejad, Z.D., Kim, J.W., Jung, M.C., 2017. Reclamation of arsenic contaminated soils around mining site using solidification/stabilization combined with revegetation. J. 21, 385-396.

41. Omran, R.G., 1980. Peroxide Levels and the Activities of Catalase, Peroxidase, and Indoleacetic Acid Oxidase during and after Chilling Cucumber Plant physiol. 65, 407-408.

42. Pardo, T., Clemente, R., Epelde, L., Garbisu, C., Bernal, M.P., 2014. Evaluation of the phytostabilisation efficiency in a trace elements contaminated soil using soil health indicators. J. Hazard. Mater. 268, 68-76.

43. Pedrosa, F.O., Monteiro, R.A., Wassem, R., Cruz, L.M., Ayub, R.A., Colauto, N.B., Fernandez, M.A., Fungaro, M.H.P., Grisard, E.C., Hungria, M., 2011. Genome of Herbaspirillum seropedicae strain SmR1, a specialized diazotrophic endophyte of tropical grasses. PLoS Genet. 7(5), 1002064.

44. Perez, R., Tapia, Y., Antilen, M., Casanova, M., Vidal, C., Santander, C., Aponte, H., Cornejo, P., 2020. Interactive effect of compost application and inoculation with the fungus Claroideoglomus claroideum in Oenothera picensis plants growing in mine tailings. Ecotoxicol. Environ. Saf. 208, 111495.

45. Pikovskaya R.I., 1948. Mobilization of phosphorus in soil in connection with the vital activity of some microbial species. Mikrobiologiya 17, 370.

46. Praburaman, L., Park, S.H., Cho, M., Lee, K.J., Ko, J.A., Han, S.S., Lee, S.H., Kamala-Kannan, S., Oh, B.T., 2017. Significance of diazotrophic plant growth-promoting Herbaspirillum GW103 on phytoextraction of Pband Zn by Zea mays L. Environ. Sci. Pollut. Res. 24, 3172-3180.

47. Prapagdee, B., Chumphonwong, N., Khonsue, N., Mongkolsuk, S., 2012. Influence of cadmium resistant bacteria on promoting plant root elongation and increasing cadmium mobilization in contaminated soil. Fresenius Environ. Bull. 21, 1186-1191.

48. Prapagdee, B., Chanprasert, M., Mongkolsuk, S., 2013. Bioaugmentation with cadmium-resistant plant growth-promoting rhizobacteria to assist cadmium phytoextraction by Helianthus annuus. Chemosphere 92, 659-666.

49. Rojjanateeranaj, P., Sangthong, C., Prapagdee, B., 2017. Enhanced cadmium phytoremediation of Glycine max through bioaugmentation of cadmium-resistant bacteria assisted by biostimulation. Chemosphere 185, 764-771.

50. Schwyn, B., Neilands, J.B., 1987. Universal chemical assay for the detection and determination of siderophores. Biochem. 160, 47-56.

51. Srivastava, S., Verma, P.C., Chaudhry, V., Singh, N., Abhilash, P., Kumar, K.V., Sharma, N., Singh, N., 2013. Influence of inoculation of arsenic-resistant Staphylococcus arlettae on growth and arsenic uptake in Brassica juncea (L.) Czern. Var. R-46. J. Hazard. Mater. 262, 1039-1047.

52. State Environmental Protection Administration of China, 2018. Soil Environmental Quality Standard of China (GB 15618-2018).

53. Sun, Y.X., Yan, C., Xu, H.L., 2017. Grassland community species diversity and aboveground biomass responses to difference in cover soil thickness in restoration after mining damage. Acta Prataculturae Sinica 26, 54-62 (in Chinese).

54. Sun, W., Xiong, Z., Chu, L., Li, W., Soares, M.A., White, J.F., Li, H., 2019. Bacterial communities of three plant species from Pb-Zn contaminated sites and plant-growth promotional benefits of endophytic Microbacterium (strain BXGe71). J. Hazard. Mater. 370,

Page 10/13 
225-231.

55. Tang, L., Hamid, Y., Zehra, A., Shohag, M.J.I., He, Z.L., Yang, X.E., 2020. Endophytic inoculation coupled with soil amendment and foliar inhibitor ensure phytoremediation and argo-production in cadmium contaminated soil under oilseed rape-rice rotation system. Sci. Total Environ. 748,142481.

56. Tortora, M.L., Díaz-Ricci, J.C., Pedraza, R.O., 2011. Azospirillum brasilense siderophores with antifungal activity against Colletotrichum acutatum. Microbiol. 193, 275-286.

57. Weyens, N., Lelie, D.V.D., Taghavi, S., Newman, L., Vangronsveld, J., 2009. Exploiting plant-microbe partnerships to improve biomass production and remediation. Trends Biotechnol. 27, 591-598.

58. Xiao, R., Ali, A., Wang, P., Li, R., Tian, X., Zhang, Z., 2019. Comparison of the feasibility of different washing solutions for combined soil washing and phytoremediation for the detoxification of cadmium (Cd) and zinc ( $\mathrm{Zn})$ in contaminated soil. Chemosphere 230 , 510-518.

59. Xu, Y., Sun, G.D., Jin, J.H., Liu, Y., Luo, M., Zhong, Z.P., Liu, Z.P., 2014. Successful bioremediation of an aged and heavily contaminated soil using a microbial/plant combination strategy. J. Hazard. Mater. 264, 430-438.

60. Zeng, H.Y., Chen, L.H., Zhou, X.H., Zeng Q.G., 2019. Cadmium accumulation in winter crops and the assessment of paddy soil phytoremediation in southern China. Environ. Sci. pollut. Res. Int. 26(17), 17173-17182.

61. Zhang, X., Gao, B., Xia, H., 2014. Effect of cadmium on growth, photosynthesis, mineral nutrition and metal accumulation of bana grass and vetiver grass. Ecotoxicol. Environ. Saf. 106, 102-108.

62. Zhang, W., Alakangas, L., Wei, Z., Long, J., 2016. Geochemical evaluation of heavy metal migration in Pb-Zn tailings covered by different topsoils. Geochem. Explor. 165, 134-142.

63. Zhang, Y.M., Li, S., Chen, Z., Wang, F., Chen, J., Wang, L.Q., 2018. A systemic ecological risk assessment based on spatial distribution and source apportionment in the abandoned lead acid battery plant zone, China. J. Hazard. Mater. 354, $170-179$.

64. Zhong, X., Chen, Z.W., Li, Y.Y., Ding, K.B., Liu, W.S., Liu, Y., Yuan, Y.Q., Zhang, M.Y., Baker, A.J.M., Yang, W.J., Fei, Y.H., Wang, Y.J., Chao, Y.Q., Qiu, R.L., 2020. Factors influencing heavy metal availability and risk assessment of soils at typical metal mines in Eastern China. J. Hazard. Mater. 400, 123289.

\section{Figures}
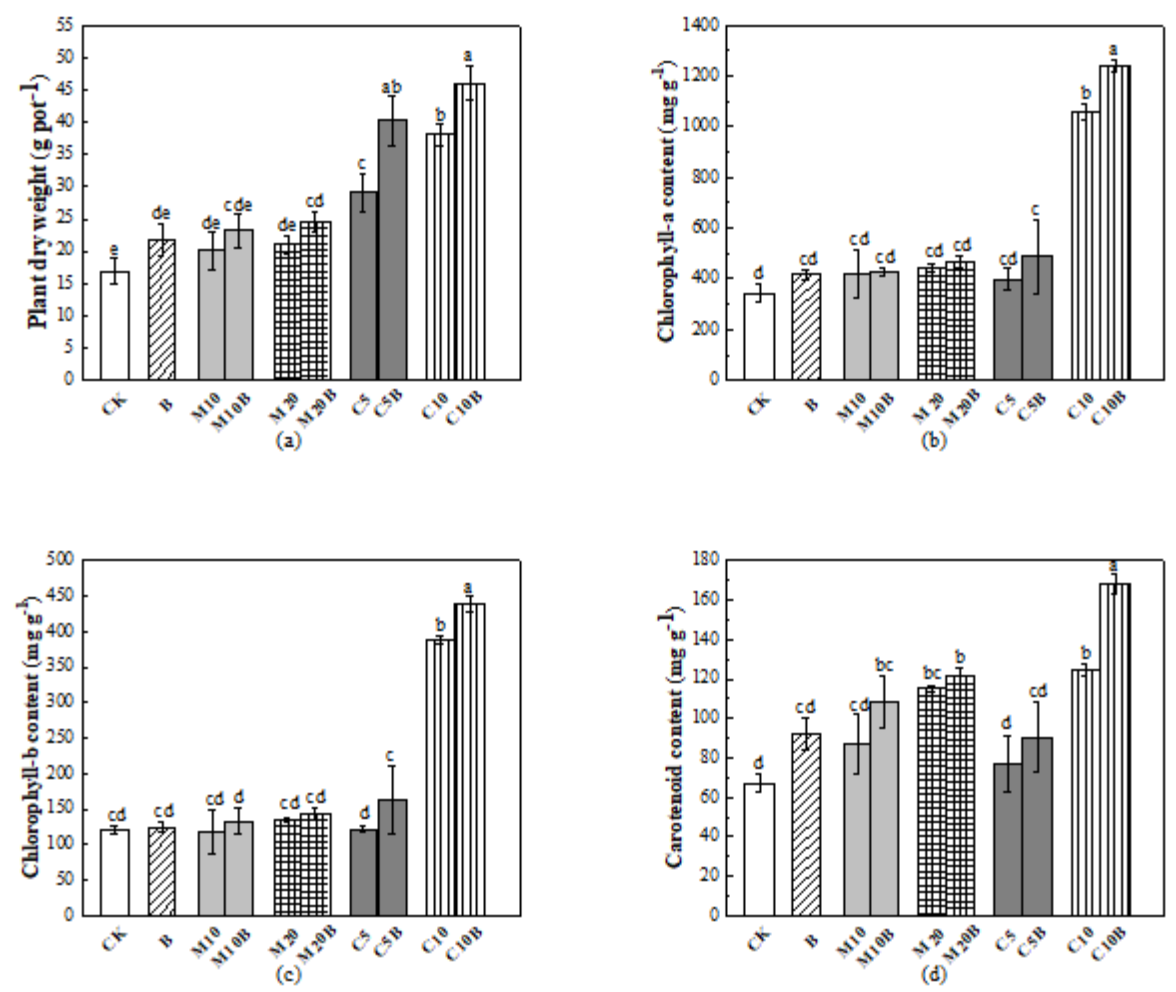

Page $11 / 13$ 


\section{Figure 1}

Plant dry weight, Chlorophyll-a, chlorophyll-b and carotenoid contents of vetiver grass with the combination of Herbaspirillum sp. p5-19

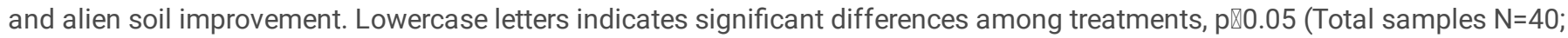
Replication $n=4)$. Notes: CK: Tailings (the un-improved control), B: Tailings with bacterial suspension (Herbaspirillum sp. p5-19), M10: 10\% soil and $90 \%$ tailings, M10B: $10 \%$ soil and $90 \%$ tailings (with bacterial suspension), M20: $20 \%$ soil and $80 \%$ tailings, M20B: $20 \%$ soil and $80 \%$ tailings (with bacterial suspension), C5: Covering $5 \mathrm{~cm}$ of soil, C5B: Covering $5 \mathrm{~cm}$ of soil (with bacterial suspension), C10: Covering $10 \mathrm{~cm}$ of soil, C10B: Covering $10 \mathrm{~cm}$ of soil (with bacterial suspension).
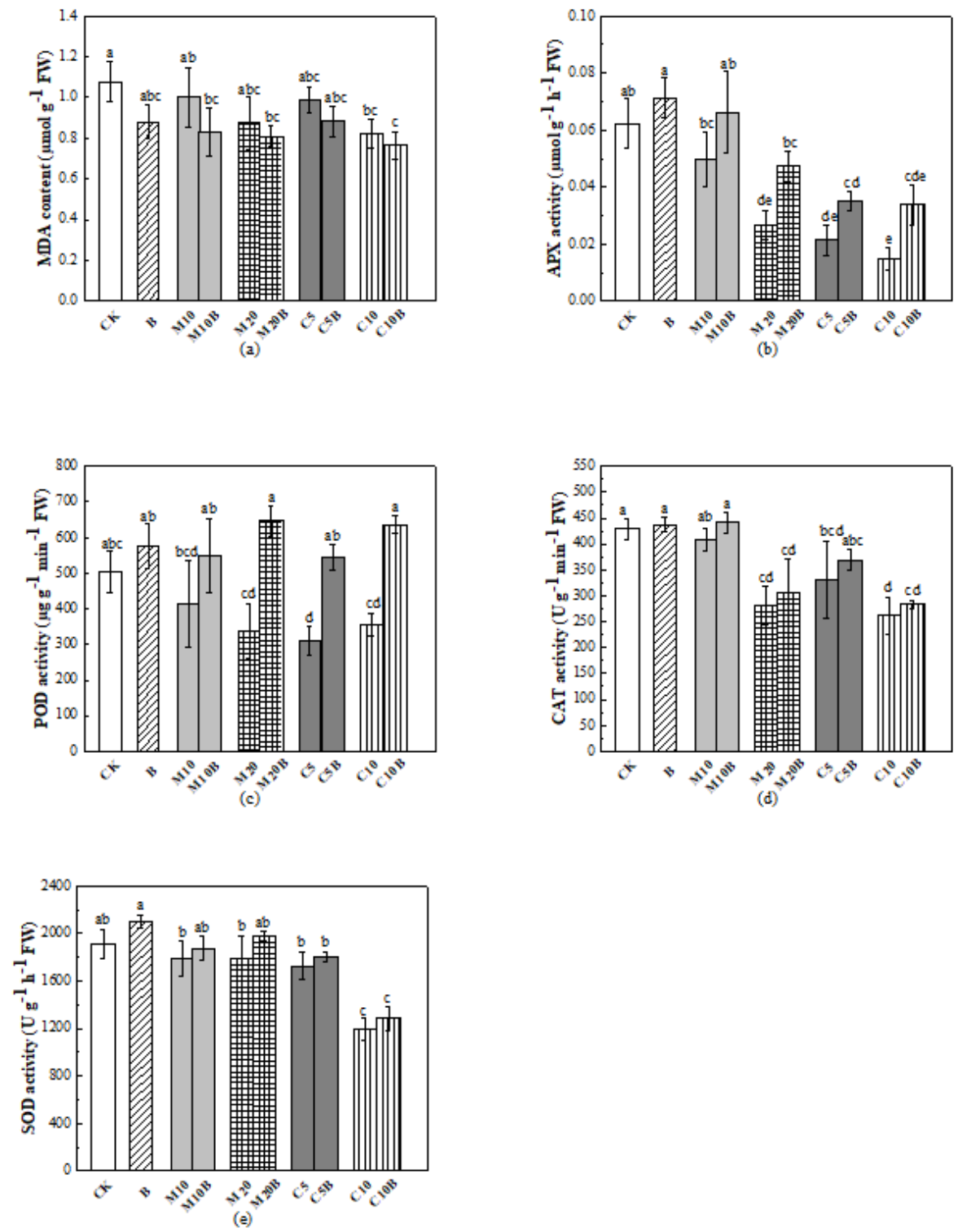

\section{Figure 2}

MDA, APX, POD, CAT, and SOD levels of vetiver grass with the combination of alien soil improvement and p5-19. Lowercase letters indicates significant differences among treatments, $\mathrm{p} \otimes 0.05$ (Total samples $\mathrm{N}=40$; Replication $\mathrm{n}=4$ ). Notes: CK: Tailings (the un-improved control), B: Tailings with bacterial suspension (Herbaspirillum sp. p5-19), M10: 10\% soil and $90 \%$ tailings, M10B: 10\% soil and $90 \%$ tailings (with bacterial suspension), M20: $20 \%$ soil and $80 \%$ tailings, M20B: $20 \%$ soil and $80 \%$ tailings (with bacterial suspension), C5: Covering $5 \mathrm{~cm}$ of soil, C5B: Covering $5 \mathrm{~cm}$ of soil (with bacterial suspension), C10: Covering $10 \mathrm{~cm}$ of soil, C10B: Covering $10 \mathrm{~cm}$ of soil (with bacterial suspension). 

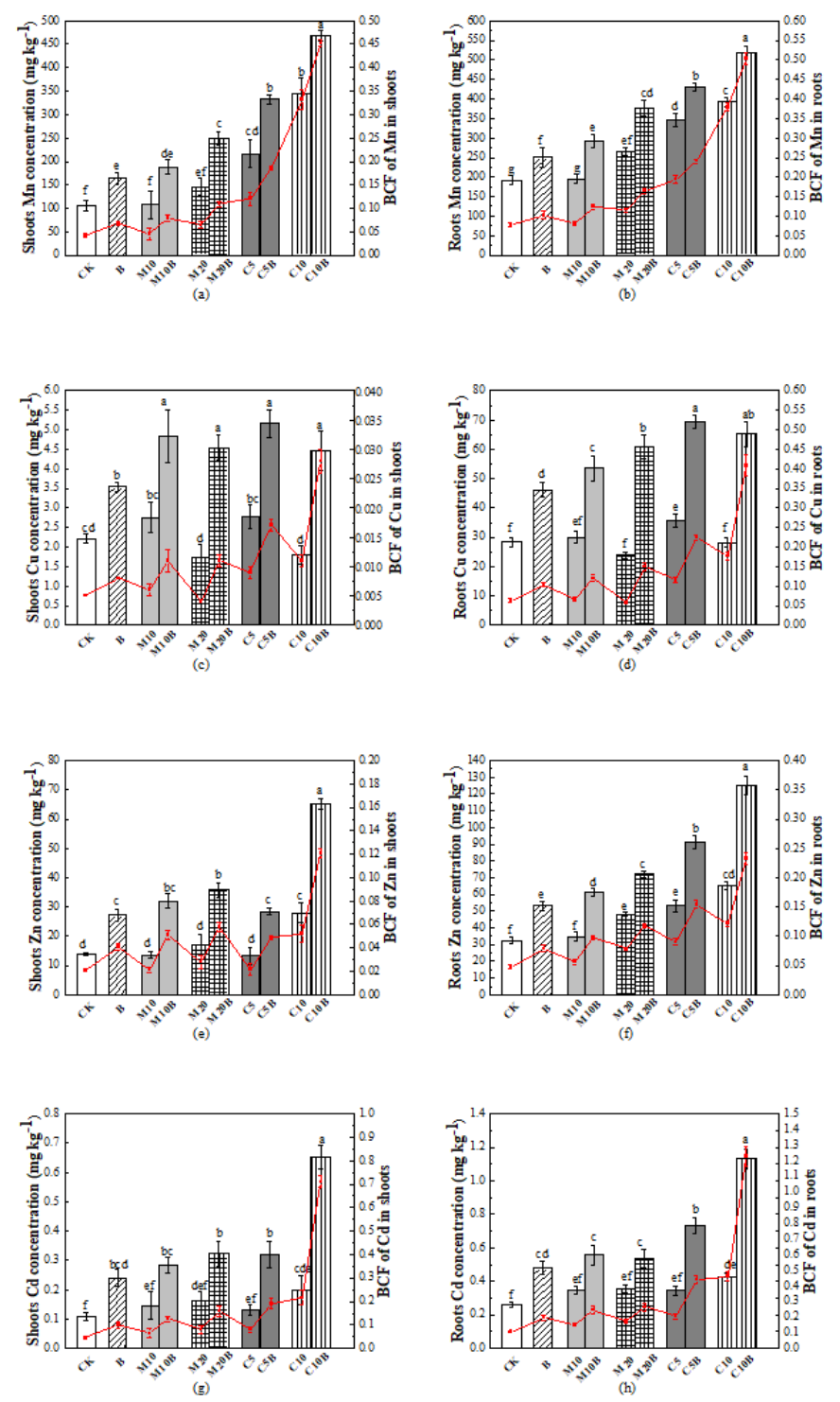

\section{Figure 3}

$\mathrm{Mn}, \mathrm{Cu}, \mathrm{Zn}$, and $\mathrm{Cd}$ concentration in vetiver grass with the combination of alien soil improvement and p5-19. Lowercase letters indicates significant differences among treatments, $\mathrm{p} \varangle 0.05$ (Total samples $\mathrm{N}=40$; Replication $\mathrm{n}=4$ ). Notes: CK: Tailings (the un-improved control), B: Tailings with bacterial suspension (Herbaspirillum sp. p5-19), M10: 10\% soil and 90\% tailings, M10B: 10\% soil and 90\% tailings (with bacterial suspension), M20: $20 \%$ soil and $80 \%$ tailings, M20B: $20 \%$ soil and $80 \%$ tailings (with bacterial suspension), C5: Covering $5 \mathrm{~cm}$ of soil, C5B: Covering $5 \mathrm{~cm}$ of soil (with bacterial suspension), C10: Covering $10 \mathrm{~cm}$ of soil, C10B: Covering $10 \mathrm{~cm}$ of soil (with bacterial suspension).

\section{Supplementary Files}

This is a list of supplementary files associated with this preprint. Click to download.

- SupplementaryMaterial.pdf 